\title{
Improvement of DFIG-based WECS Performance Using SMES unit
}

\author{
Mahmoud Y. Khamaira \\ Electrical and Computer \\ Engineering Department \\ Curtin University \\ Perth, Australia \\ m.khamaira@postgrad.curtin.edu.au
}

\author{
A. M. Shiddiq Yunus \\ Mechanical Eng. Dept. Energy \\ Conv. Study Program, State \\ Polytechnic of Ujung Pandang \\ Makassar, Indonesia \\ shiddiq@poliupg.ac.id
}

\author{
A. Abu-Siada \\ Electrical and Computer \\ Engineering Department \\ Curtin University \\ Perth, Australia \\ A.AbuSiada@curtin.eu.au
}

\begin{abstract}
Doubly Fed Induction Generators (DFIGs) are widely used in variable speed wind turbine owing to its superior advantages that include ability to extract more energy from turbine, capability to control active and reactive power independently and the usage of reduced converter rating that reduces its overall cost. The application of DFIG in large wind energy conversion systems (WECS) has reached $55 \%$ of the worldwide total wind capacity during the year 2012. On the other side fluctuating output power, weak fault ride through capability and high sensitivity to grid disturbances are the main issues that affect DFIG performance. In this paper, superconducting magnetic energy storage (SMES) unit is proposed to improve the overall performance of a DFIG-based WECS during voltage sag disturbance in the grid side. A new control approach for SMES unit using hysteresis current controller (HCC) along with proportional integral (PI) controller is introduced. Simulations results reveal the effectiveness of the proposed SMES controller in improving the overall performance of the WECS system under study.
\end{abstract}

\section{Index Terms - DFIG, WECS, SMES}

\section{INTRODUCTION}

Due to the degradation and cost increase of conventional fossil fuel along with the global trend to decrease the greenhouse effect, clean energy production from renewable sources has been given a great concern during the last few decades. Among those, wind energy conversion system (WECS) has received a remarkable attraction during last ten years. The global installed capacity worldwide significantly increased from $7.272 \mathrm{GW}$ at the end of the year 2002 to $44.799 \mathrm{GW}$ by the end of the year 2012 [1]. In 2008, wind power produced over $1 \%$ of global electricity generation and by the year 2020, it is estimated to produce about $10 \%$ of the global electricity [2]. With the fast growth of power electronics technology, the concept of a variable-speed wind turbine equipped with a doubly fed induction generator (DFIG) is receiving more attention because of its advantages over other wind turbine generator concepts. The typical configuration of DFIG is shown in Fig. 1 where the stator winding of the generator is directly coupled to the grid at a point of common coupling (PCC) through a coupling transformer whereas the rotor winding is fed via a partially rated $(25 \%-30 \%$ of the DFIG rated power) variable frequency $\mathrm{AC}-\mathrm{DC}-\mathrm{AC}$ converter. The $\mathrm{AC} / \mathrm{DC} / \mathrm{AC}$ converters include a rotor-side converter (RSC) and a grid-side converter (GSC) linked by DC link capacitor $[3,4]$.

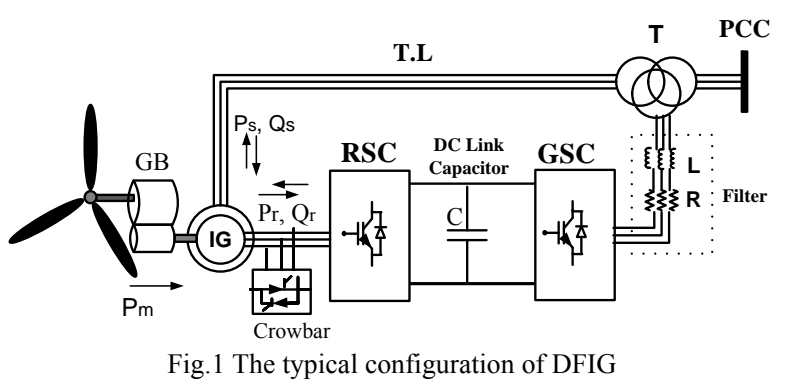

At early stages of its implementation, it was allowed to disconnect the wind turbines during various grid faults to protect it from being damaged. Nowadays, and due to the significant portion of load that wind farms contribute, transmission line operators (TLOs) require the wind turbine to remain connected to support the grid during grid disturbance events. This has led to the establishment of strict grid codes that wind turbine generator must meet to maintain its connection to the grid. While many papers can be found in the literature investigating various approaches to compensate WECS reactive power during fault events by mainly connecting a flexible AC transmission system (FACTS) device such as static synchronous compensator (STATCOM) to the PCC [4-6], a few publications considered the compensation of active power as well [7, 8].

Superconducting magnetic energy storage (SMES) unit is a FACTS device that can compensate both active and reactive power smoothly, independently and rapidly in four quadrant operation [9]. Application of superconducting magnetic energy storage (SMES) unit to smooth the output power of fixed speed-based WECS during wind speed fluctuation and its applications to improve the dynamic performance of 
variable speed-based WECS have been investigated in the literature [10-19].

This paper presents an application for SMES unit to improve the overall performance of a DFIG based WECS during voltage sag at the grid side. A new SMES control system, which is efficient, simple, and easy to implement, is proposed. Simulation is carried out using Simulink/Matlab software.

\section{SYSTEM UNDER STUDY}

Fig. 2 shows the system under study that consists of six 1.5-MW DFIGs connected to the ac grid at the PCC. The grid that is represented by an ideal threephase voltage source of constant frequency is connected to the wind turbines via a $30-\mathrm{km}$ transmission line and step-up transformer. The reactive power produced by the wind turbines is regulated at zero MVar under normal operating conditions to maintain unity power factor connection.

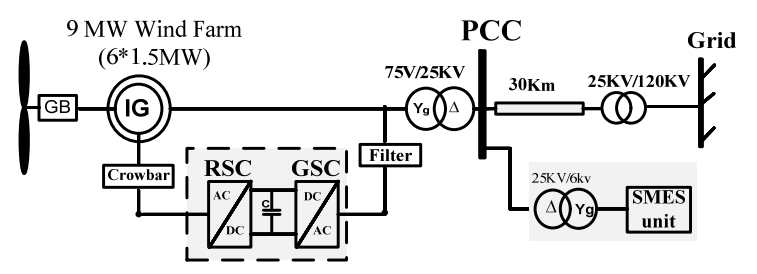

Fig. 2 system under study

For an average wind speed of $15 \mathrm{~m} / \mathrm{s}$, which is used in this study, the turbine output power is $1.0 \mathrm{pu}$, and the rotor shaft speed is $1.2 \mathrm{pu}$. The SMES unit is linked to the $25-\mathrm{kV}$ bus through a step up $\mathrm{Y}-\Delta$ transformer and is assumed to be fully charged [15].

\section{CONTROL SYSTEM OF SMES UNIT}

Fig. 3 shows the typical configuration of the proposed SMES unit, which consists of a Wye-Delta transformer, a six-pulse width modulation (PWM) rectifier/inverter using insulated gate bipolar transistor (IGBT), a two-quadrant dc-dc chopper using IGBT, and a superconducting coil.

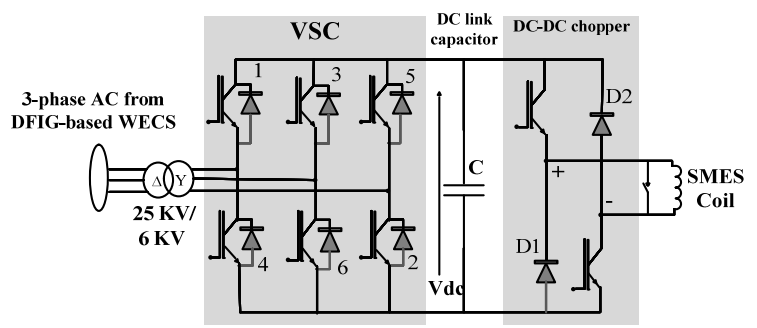

Fig. 3 Typical configuration of SMES unit

The PWM converter and the dc-dc chopper are linked by a dc link capacitor [20]. This configuration makes SMES highly efficient in storing electricity with typical efficiency in the range of $95 \%-98 \%$ [14]. Other advantages of the SMES unit include very quick response and possibilities for high-power applications [21]. The stored energy in the SMES coil can be calculated as [20]

$$
E_{s m s}=\frac{1}{2} I_{s m s}^{2} L_{s m s}
$$

where $E_{s m s}, L_{s m s}$, and $I_{s m s}$ are the stored energy, superconductor inductance, and the dc current through the SMES coil respectively.

To control the power exchange between SMES unit and the grid, hysteresis current control (HCC) is chosen based on its advantages including simplicity, fast dynamic response, maximum current limit and insensitivity to load parameter variations [22]. As can be seen in the Fig. 4, the basic implementation of the HCC is based on deriving the converter switching signals from the comparison of the actual phase currents with a fixed tolerance band around the reference current associated with that phase. The HCC is comparing the three-phase line currents $\left(I_{a b c}\right)$ with the reference currents $\left(I_{a b c}^{*}\right)$, which is dictated by the $I_{d}^{*}$ and $I_{q}^{*}$ references. The values of $I_{d}^{*}$ and $I_{q}^{*}$ are generated through conventional PI controllers based on the error values of $V_{d c}$ and $V_{g}$. The value of $I_{d}^{*}$ and $I_{q}^{*}$ is converted through Park transformation $(d q 0-a b c)$ to produce the reference current $\left(I_{a b c}^{*}\right)$ [15].

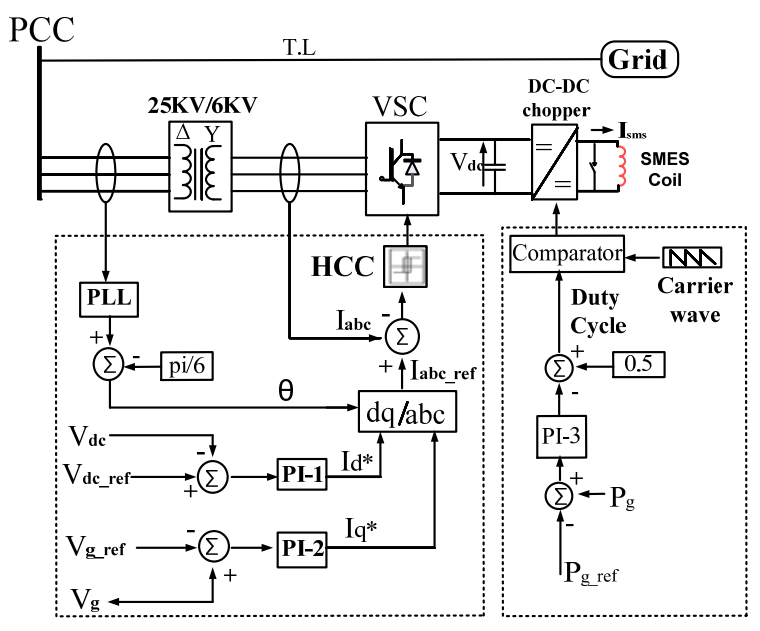

Fig. 4 Control system of SMES unit

The superconducting coil is charged or discharged by adjusting the average voltage, $V_{\text {sms av }}$, across the coil which is determined by the duty cycle $(D)$ of the two quadrant DC-DC chopper. To determine the value of the duty cycle of the DC-DC chopper, the power generation is used as input to a proportional integral (PI) controller. Based on this concept, the control system of a DC-DC chopper is constructed as shown in Fig. 4. Under normal operating condition, duty cycle is equal to 0.5 and there is no power exchange between the SMES unit and the grid. During grid disturbance events that call for power support such as voltage dips, the PI controller acts to adapt the duty cycle to be in the range of 0 to 0.5 and the stored energy in the coil will be transferred to the grid (Discharging mode). The charging mode of the SMES coil takes place when duty cycle is within the 
range of 0.5 to 1 . The relation between $V_{s m s}$ and $V_{d c_{-} s m s}$ can be written as $[23,24]$

$V_{\text {sms_av }}=[1-2 D] V_{d c_{-} a v}$

where $V_{\text {sms_av }}$ is the average voltage across the SMES coil, $D$ is duty cycle, and $V_{d c_{-} s m s}$ is the average voltage across the dc-link capacitor of the SMES configuration.

\section{SIMULATION RESULTS}

To assess the effectiveness of the proposed SMES controller, a voltage sag of $0.3 \mathrm{pu}$ is applied from $t=$ $3 \mathrm{~s}$ to $t=4 \mathrm{~s}$ at the grid side of the system shown in Fig. 2. Figs. 5-11 show the performance of the studied system without and with the proposed SMES controller during such event. The voltage profile at the PCC is shown in Fig. 5, where without SMES, voltage will drop to $0.2 \mathrm{pu}$. By connecting the SMES unit, voltage drop at the PCC will be raised to 0.65 $\mathrm{pu}$ due to reactive power support by the SMES. Compared with the fault ride through of Spain, Denmark and Germany, the voltage at the PCC violates the low voltage ride through (LVRT) of all of the mentioned grid codes when the SMES unit is not connected as shown in Fig. 6 which calls for the disconnection of the wind turbine from the grid. By connecting the SMES unit to the PCC bus, the amount of voltage drop decreases and reaches a safe level of the grids requirement (Fig. 6) and therefore the wind turbine connection to the grid is maintained.

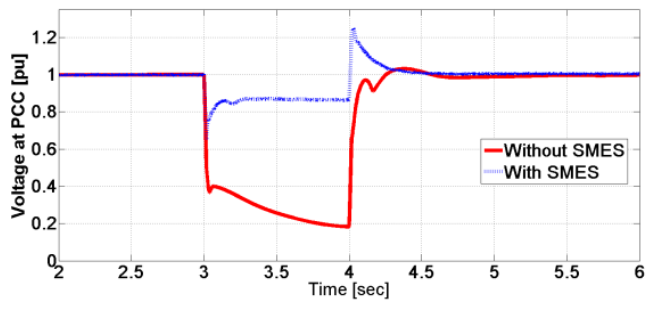

Fig. 5 PCC voltage profile

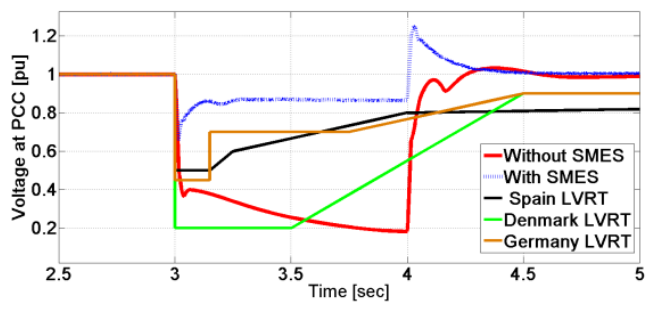

Fig. 6 PCC voltage compliance with various grid codes

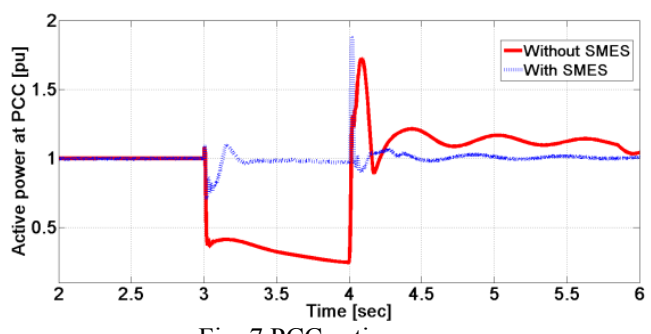

Fig. 7 PCC active power

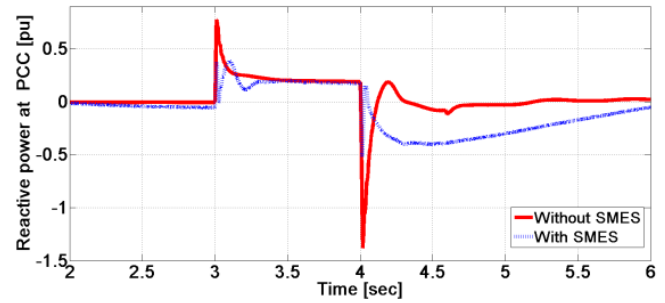

Fig. 8 PCC reactive power

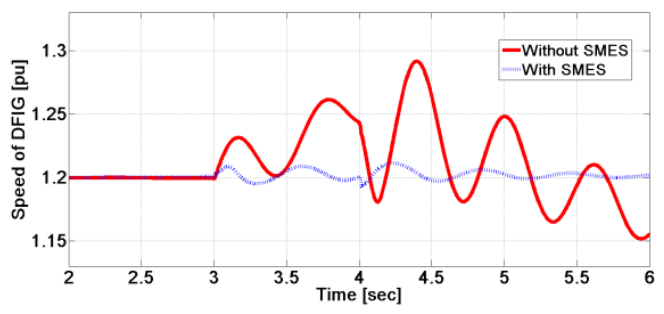

Fig. 9 DFIG speed

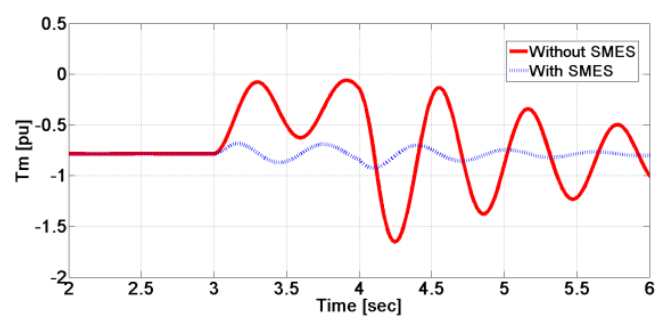

Fig. 10 Mechanical torque

Due to the fault and without the connection of the SMES unit, the active power at the PCC will drop to $0.25 \mathrm{pu}$, and it reaches a maximum overshooting of $75 \%$ during the clearance of the fault, as shown in Fig. 7. When the SMES is connected to the system, the active power at the PCC will be compensated to reach its nominal level during the fault as shown in Fig. 7. Fig. 8 shows the reactive power at the PCC without and with the connection of the SMES unit. Without SMES, more reactive power will be withdrawn from the DFIG while with the support of SMES unit; less reactive power will be needed from the DFIG. The DFIG power drop causes the generator speed to be accelerated to compensate for the power imbalance. As can be observed in Fig. 9, the generator speed will accelerate and oscillate without the SMES unit; however, with the SMES connected to the system, the power drop is reduced, the settling time of the generator speed is substantially reduced, and the overshooting level is significantly decreased. Same trend can be observed in the shaft mechanical torque shown in Fig. 10. Fig. 11 shows the voltage across the DFIG dc link capacitor which experiences a sever overshooting during fault clearance. With the SMES unit connected to the system, this maximum shooting is substantially reduced. 


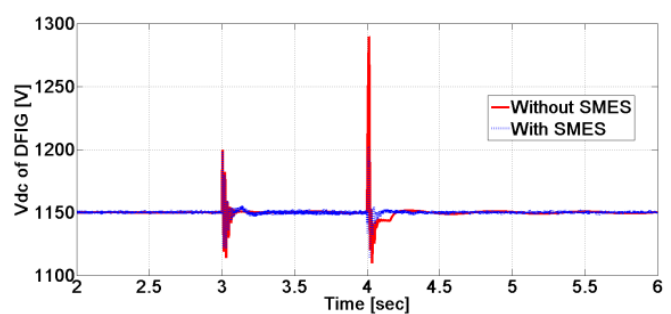

Fig. 11 Voltage at the dc-link of the DFIG

The SMES unit behaviour during voltage sag event can be investigated through Figs. 12-15 which respectively show the duty cycle, the voltage across the coil, SMES current, and SMES coil stored energy. Before the fault application and during normal operating conditions, the duty cycle is maintained at 0.5 level and the voltage across the SMES coil is maintained at zero level which is corresponding to maximum coil current and rated energy stored. Upon the occurrence of voltage sag, the PI controller acts to reduce the duty cycle to a level less than 0.5 that creates a negative voltage across the coil and the current will be reduced accordingly allowing portion of its stored energy to be delivered to the grid. When the fault is cleared the PI controller acts to retain the duty cycle level to 0.5 again.

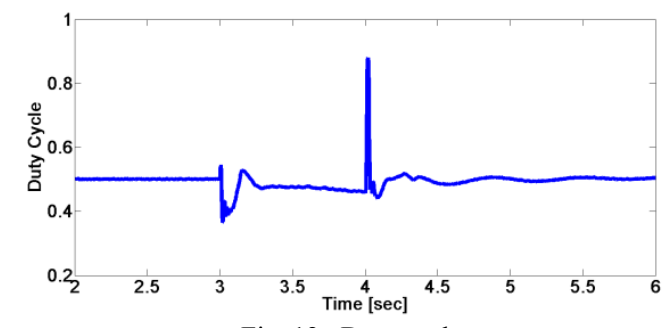

Fig. 12 . Duty cycle

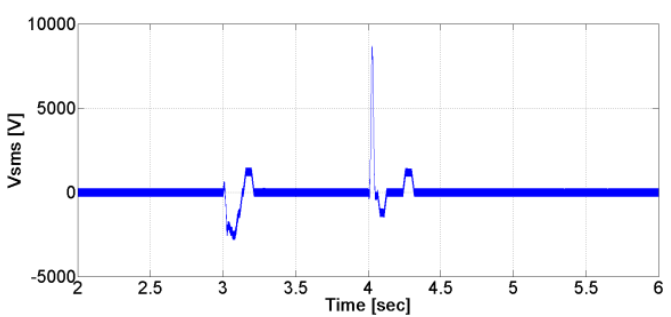

Fig. 13 Voltahe across SMES coil

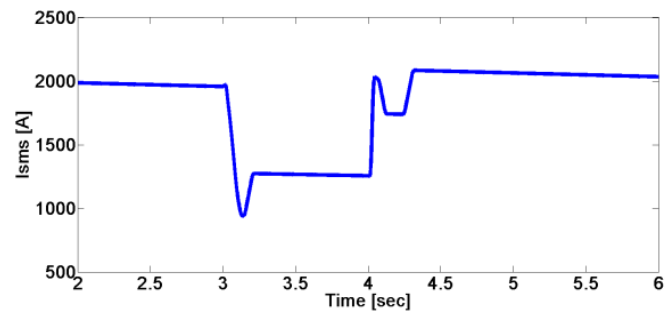

Fig. 14 SMES current

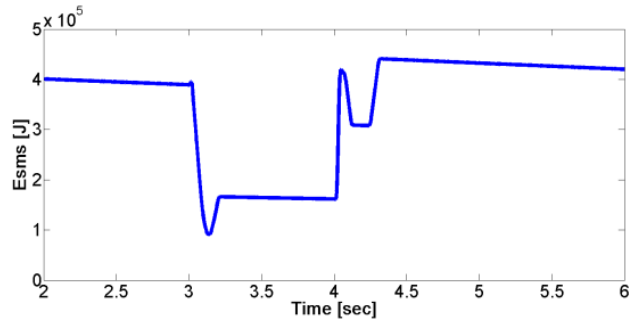

Fig. 15 Stored energy of SMES unit

\section{SMES UNIT COST}

The SMES system is still expensive due to the cryogenic system equipped with liquid helium that is required to maintain the SMES coil within the superconducting state. However, with the recent development of high-temperature superconductors equipped with less expensive liquid nitrogen as a cryogenic medium, the cost of SMES is becoming commercially affordable $[9,14,21]$.

\section{CONCLUSION}

A simple SMES control approach to improve the overall performance of a DFIG-based WECS is proposed. The approach is realized through simple $\mathrm{HC}$ and PI controllers. Simulation results show that the SMES unit based HCC and PI controller is very effective in improving the dynamic performance of the DFIG during voltage sag at the grid side and can bring the voltage profile at the PCC to a safe level that comply with various LVRT grid codes. The proposed control algorithm of the SMES unit is simple and easy to implement.

\section{APPENDIX}

PARAMETERS OF PI CONTROLLER

\begin{tabular}{|c|c|c|c|}
\hline & PI-1 & PI-2 & PI-3 \\
\hline$K_{p}$ & 1 & 0.3 & 0.5 \\
\hline$K_{i}$ & 3 & 3 & 1 \\
\hline
\end{tabular}

PARAMETERS OF SMES UNIT

\begin{tabular}{|c|c|}
\hline SC inductor & $0.2 \mathrm{H}$ \\
\hline Rating current & $2 \mathrm{KA}$ \\
\hline DC link capacitor & $18000 \mu \mathrm{F}$ \\
\hline
\end{tabular}

\section{ACKNOWLEDGMENT}

The first author would like to thank the Higher Education Ministry of Libya for providing him with scholarship at Curtin University, Australia.

\section{REFERENCE}

[1] "www.gwec.net."

[2] P. Musgrove, in Wind power, ed New York: Cambridge Univ. Press, 2010, pp. 221-222.

[3] L. Shuhui and T. A. Haskew, "Analysis of Decoupled $\mathrm{d}-\mathrm{q}$ Vector Control in DFIG Back-to-Back PWM Converter," in Power Engineering Society General Meeting, 2007. IEEE, 2007, pp. 1-7. 
Q. Wei, G. K. Venayagamoorthy, and R. G. Harley, "Real-Time Implementation of a STATCOM on a Wind Farm Equipped With Doubly Fed Induction Generators," Industry Applications, IEEE Transactions on, vol. 45, pp. 98-107, 2009.

[5] A. F. Abdou, A. Abu-Siada, and H. R. Pota, "Application of STATCOM to improve the LVRT of DFIG during RSC fire-through fault," in Universities Power Engineering Conference (AUPEC), 2012 22nd Australasian, 2012, pp. 1-6.

[6] C. Liu, Y. Kang, J. Chen, L. Kevin, X. Lin, X. Liu, and F. Xu, "Simplified Active and Reactive Power Control of Doubly Fed Induction Generator and the Simulation with STATCOM," in Applied Power Electronics Conference and Exposition, 2009. APEC 2009. TwentyFourth Annual IEEE, 2009, pp. 1927-1931.

[7] M. Ferdosian, H. Abdi, and A. Bazaei, "Improved dynamic performance of wind energy conversion system by UPFC," in Industrial Technology (ICIT), 2013 IEEE International Conference on, 2013, pp. 545550.

[8] M. T. Hagh, A. Lafzi, and A. R. Milani, "Dynamic and stability improvement of a wind farm connected to grid using UPFC," in Industrial Technology, 2008. ICIT 2008. IEEE International Conference on, 2008, pp. 1-5.

[9] A. Abu-Siada and S. Islam, "Application of SMES Unit in Improving the Performance of an AC/DC Power System," Sustainable Energy, IEEE Transactions on, vol. 2, pp. 109-121, 2011.

[10] F. Zhou, G. Joos, C. Abbey, L. Jiao, and B. T. Ooi, "Use of large capacity SMES to improve the power quality and stability of wind farms," in Power Engineering Society General Meeting, 2004. IEEE, 2004, pp. 2025-2030 Vol.2.

[11] S. Jing, T. Yuejing, Y. Tao, L. Jingdong, and C. Shijie, "Study on Control Method of Voltage Source Power Conditioning System for SMES," in Transmission and Distribution Conference and Exhibition: Asia and Pacific, 2005 IEEE/PES, 2005, pp. 1-6.

[12] T. Asao, R. Takahashi, T. Murata, J. Tamura, M. Kubo, A. Kuwayama, and T. Matsumoto, "Smoothing control of wind power generator output by superconducting magnetic energy storage system," in Electrical Machines and Systems, 2007. ICEMS. International Conference on, 2007, pp. 302-307.

[13] I. Ngamroo, A. N. Cuk Supriyadi, S. Dechanupaprittha, and Y. Mitani, "Power oscillation suppression by robust SMES in power system with large wind power penetration," Physica C: Superconductivity, vol. 469, pp. 44-51, 2009.

[14] M. H. Ali, P. Minwon, Y. In-Keun, T. Murata, and J. Tamura, "Improvement of Wind-Generator Stability by Fuzzy-Logic-Controlled SMES," Industry Applications, IEEE Transactions on, vol. 45, pp. 1045-1051, 2009

[15] A. M. S. Yunus, M. A. S. Masoum, and A. Abu-Siada, "Application of SMES to Enhance the Dynamic Performance of DFIG During Voltage Sag and Swell," Applied Superconductivity, IEEE Transactions on, vol. 22, pp. 5702009-5702009, 2012

[16] S. Jing, T. Yuejin, X. Yajun, R. Li, and L. Jingdong, "SMES Based Excitation System for Doubly-Fed Induction Generator in Wind Power Application," Applied Superconductivity, IEEE Transactions on, vol. 21, pp. 1105-1108, 2011.

[17] G. Wenyong, X. Liye, and D. Shaotao, "Enhancing Low-Voltage Ride-Through Capability and Smoothing Output Power of DFIG With a Superconducting FaultCurrent Limiter\&\#x2013;Magnetic Energy Storage System," Energy Conversion, IEEE Transactions on, vol. 27, pp. 277-295, 2012.

[18] N. Taesik, S. Jae Woong, and H. Kyeon, "The Beneficial Role of SMES Coil in DC Lines as an Energy Buffer for Integrating Large Scale Wind Power," Applied Superconductivity, IEEE Transactions on, vol. 22, pp. 5701404-5701404, 2012.
[19] M. E. Elshiekh, D. A. Mansour, and A. M. Azmy, "Improving Fault Ride-Through Capability of DFIGBased Wind Turbine Using Superconducting Fault Current Limiter," Applied Superconductivity, IEEE Transactions on, vol. 23, pp. 5601204-5601204, 2013.

[20] M. H. Ali, W. Bin, and R. A. Dougal, "An Overview of SMES Applications in Power and Energy Systems," Sustainable Energy, IEEE Transactions on, vol. 1, pp. $38-47,2010$

[21] A. M. Shiddiq Yunus, A. Abu-Siada, and M. A. S. Masoum, "Application of SMES Unit to Improve DFIG Power Dispatch and Dynamic Performance During Intermittent Misfire and Fire-Through Faults," Applied Superconductivity, IEEE Transactions on, vol. 23, pp. 5701712-5701712, 2013.

[22] M. P. Kazmierkowski and L. Malesani, "Current control techniques for three-phase voltage-source PWM converters: a survey," Industrial Electronics, IEEE Transactions on, vol. 45, pp. 691-703, 1998.

[23] M. R. I. Sheikh, S. M. Muyeen, R. Takahashi, T. Murata, and J. Tamura, "Transient stability enhancement of wind generator using superconducting magnetic energy storage unit," in Electrical Machines, 2008. ICEM 2008. 18th International Conference on, 2008, pp. 1-6.

[24] M. H. Ali, J. Tamura, and W. Bin, "SMES strategy to minimize frequency fluctuations of wind generator system," in Industrial Electronics, 2008. IECON 2008. 34th Annual Conference of IEEE, 2008, pp. 3382-3387. 